UDC 34.02(476):002

DOI https://doi.org/10.32836/2521-6473-2018-2-175-183

\author{
I. I. Liaskouski, Master of Laws, \\ Graduate Student of the Department of Constitutional \\ Law of the Faculty of Law, Belarusian State University
}

\title{
REPUBLIC OF BELARUS. RESTRICTED INFORMATION MODE. CONFIDENTIAL INFORMATION AND SECRETS
}

The issue of access of citizens and legal entities to information of limited access is being considered. Analyzed international treaties, regulatory legal acts of the Republic of Belarus governing the issues of access to information.

The definition of confidential information, which information refers to secrets.

In order to streamline relations in the field of information, each state creates a system for protecting information, sets restrictions on access and distribution of a particular type of information. In this way, conditions are created for the protection of information, the dissemination of which constitutes a threat to the exercise of the rights and legitimate interests of subjects. On the other hand, the establishment of a legal regime of open and publicly available information, combined with exceptions to it, allows us to form the basis for balancing the interests of society and the state in models of social relations within the framework of a democratic social law-based state.

The introduction and implementation of the legal regime of restricted access information is associated not only with ensuring general security, but also with the goal of regulating the interaction of state bodies and individuals. The term "interaction" describes only one aspect of relations between state bodies and citizens, and is more concerned with the latter's assistance in the realization of their rights and freedoms. It should be borne in mind that for citizens not only the full realization of rights and freedoms is important, but also their real protection and restoration, which is an essential factor in determining the goal of establishing legal regimes of information of limited access.

Key words: state, public relations, limited access, information mode, secrets.

I. І. Лясковський. Республіка Білорусь. Обмежений інформаційний режим. Конфіденційна інформація та таємниця

Розглядається правове регулювання основ режиму інформаиії обмеженого доступу з використанням міжнародних актів (договорів), нормативних правових актів Республіки Білорусь, способи доступ громадян, юридичних осіб до даного виду інформації. Дається визначення понять «конфідениійна інформація», «таємна інформачія».

Кожна держава з метою впорядкування відносин у сфері інформащії створює систему захисту інформації, встановлює обмеження доступу і поширення того чи іншого виду інформації.

Ключові слова: держава, зв'язки із громадськістю, обмежений доступ, інформачійний режим, таємниці.

Problem formulation. The effective functioning of the information sphere is the key to the development of society. The introduction of information and telecommunication technologies in various spheres of social life, in particular, in the work of government bodies has both positive and negative consequences. On the one hand, the legitimate use of the capabilities of the above-mentioned technologies helps every person, society and the state apparatus to more effectively satisfy their own interests and fulfill their duties. On the other hand, the use of information can bring substantial harm to each of these subjects.

Analysis of recent researches and publications. The problem of preventing security threats and violations of the rule of law in connection with the circulation of information was

\section{(C) I. I. Liaskouski, 2018}

ISSN 2521-6473 
recognized at the international level for a long time. One of the first international treaties concerning the restriction of access to information is the Universal Declaration of Human Rights, adopted by resolution 217A (III) of the UN General Assembly of December 10, 1948. In Art. 12 of the document establishes the right of everyone to protect the secrecy of correspondence from interference with personal and family life. Final norms in Art. 28-29 are drawn up in the spirit of a general legal axiom about the relationship between human rights and the obligations arising before society towards them, thereby providing for the possibility of restricting the right to information "with the goal of ensuring due recognition and respect for the rights and freedoms of others order and general welfare in a democratic society" [2].

Goal and tasks. The content of information (in view of its potential social utility or danger), as well as all stages of its turnover (collection, storage, use and distribution) require a clear mechanism for the legal regulation of information relations, the development of effective legal means for exercising information rights and freedoms of a person and citizen, provided information security.

Main material. The text of the European Convention for the Protection of Human Rights and Fundamental Freedoms already explicitly states that, next to the human right to freedom to receive and impart information, there are duties and responsibilities related to the need for everyone to respect other people's similar rights, as well as to comply with the regulatory requirements associated with their provision, and ensuring general security. Thus, paragraph 2 of Article 10 allows states to establish formalities, conditions, restrictions or sanctions (acceptable from the point of view of values of a democratic society) in the interests of national security, territorial integrity or public order "to prevent unrest or crime, to protect health and morals, protecting the reputation or rights of others, preventing the disclosure of information received in confidence, or ensuring the authority and impartiality of justice".

Also in part 2 of Article 8 of this document stresses the inadmissibility of violation by public authorities of the right of everyone to respect for personal and family life, home and correspondence [6].

An important feature of the provisions of international documents adopted in the period 1948-1966. We consider focusing on the need for states to observe democratic principles while legislatively establishing exceptions to the right to privacy of correspondence and the right to freedom to receive and impart information. Obviously, this requirement also applies to the establishment of a list of information, the restriction of access to which is necessary to ensure state security, law and order, etc.

Also noteworthy is the emphasis on the restriction of public authorities in the possibility of violating the secrecy of private correspondence. Equally attention is paid to the fact that everyone should respect the similar rights of all other people. It is obvious that these requirements are considered as guidelines in the preparation of national legislation in the field of the protection of confidential information and state secrets.

A number of later international agreements adopted since the 1980s. Twentieth century. Specify the boundaries of the realization of the right to information regarding information related to the state, economic, public and the interests of individuals. Thus, the Aarhus Convention considered earlier in paragraph 4 of Article 4 provides for the right of a state body to refuse to receive information, if its disclosure may adversely affect:

- the confidentiality of the work of state bodies (in the event that such a special regime of their activities is provided by law);

- national security and defense interests, as well as international relations;

- the administration of justice (in specified cases);

- the confidentiality of commercial and industrial information (except for information on emissions), if such a special regime is associated with the protection of legitimate economic interests and is established by law); 
- intellectual property rights;

- confidentiality of personal data and / or archives relating to an individual in the absence of permission to provide such information;

- the interests of the third party who submitted such information, if it did not consent to their dissemination, or is not obliged by law to disclose such information;

- the state of the environment in special cases (for example, information on the distribution areas of endangered species).

It is also noted that the decision to provide or limit such information is made taking into account the public interest in disclosing it and taking into account whether the requested information is related to emissions into the environment [5].

The UN Convention against Transnational Organized Crime, adopted by General Assembly resolution 55/25 of November 15,2000 , adopted such a rule regarding bank secrecy: according to paragraph 6 of Article 12, its protection cannot be a ground for refusing to issue a ruling, judicial or other Competent authority on the provision of banking, financial and commercial documents [8].

The International Convention for the Suppression of the Financing of Terrorism, adopted by General Assembly resolution 54/109 of December 9, 1999, contains a similar rule. According to paragraph 2 of Article 12, States Parties are not entitled to reject requests of other States Parties for mutual legal assistance, referring to bank secrecy. With regard to confidential information, such information may be any evidence available to the requested party for a criminal investigation [9].

It should be noted that in the framework of this document we are talking about such types of information of limited access as the secret of the home, personal information (paragraph 2 of Article 24).

In general, as you can see, international agreements rather briefly deal with issues of limited access information. The exception to the overwhelming majority is the Convention on the Protection of Individuals in the Automatic Processing of Personal Data of January 28, 1981. Based on the content of the preamble, this agreement attempts to regulate relations in the field of personal data turnover between states, on the one hand, in view of the implementation of generally accepted rules on respect for privacy, and on the other hand, in view of ensuring effective international interaction in the face of increasing cross-border flow of personal data, subjected to automated processing [7].

Here, regime requirements are aimed at restricting arbitrary and unlawful access and use of data. It also justifies the need to limit the list of used information about an individual (relating to his private life).

Further development of the international regulation of personal information was carried out in European legislation by Directive 95/46 / EC of the European Parliament and of the Council of 24 October 1995 "On the protection of individuals with regard to the processing of personal data and on the free movement of such data" [3].

Summarizing the results of consideration of the legal basis of information of limited access in international agreements allows to draw such conclusions. First, the specification of the areas of public relations concerning the circulation of information of limited access serves as the basis for establishing special legal regimes for: state secrets; official secrets; confidential information.

Secondly, while justifying restrictions on access and dissemination of information, the international community is guided by the desire to create a basis for ensuring basic human rights, and also to establish a reasonable balance - within the principles of a democratic state - between the interests of national security and the exercise of public functions on the one hand, and the interests of individuals and legal entities, society at large, on the other hand.

Thirdly, a list of goals of restricting the right to information, which should guide the public bodies of the states parties to international agreements (in particular, the interests of state security, protecting public health and the environment, ensuring law and order, protecting the morality of society, protecting human rights in the field of information) rights to respect for personal and family life, etc.).

ISSN 2521-6473

Правова позиція, № 2 (21), 2018 
The provisions of international treaties on information of limited access are disclosed and specified in national legislation, where the key importance belongs to the norms of the Constitution of the Republic of Belarus ${ }^{1}$.

The Basic Law implements a fundamentally important idea of international documents that restricting the right to information by introducing a special legal regime is possible for exclusive purposes. Such goals in Article 23 recognize the interests of national security, public order, the protection of morality, public health, and the rights and freedoms of others; such restrictions may be imposed solely through legislation.

This is in accordance with the Belarusian legislation the generally accepted thesis about the relationship of human rights and freedoms with the range of responsibilities to other people and public interests. The state, in turn, ensuring the protection of rights and interests in the field of information, has the right to limit them for the purposes indicated above.

A consistent review of constitutional norms leads to the conclusion that the Basic Law lays down the legal foundations for:

- protection of the secrecy of correspondence, telephone and other communications (Art. 28);

- restrictions on access to information constituting state secrets, proprietary or confidential information (part 3 of Article 34);

- protection of the secrecy of voting, as an element of the electoral process (Art. Art. 38, 68, 76, 81) and the method of decision-making in personnel matters in government bodies (Art. Art. 91, 103).

Comparing these norms, we see that only the regime of secrecy of correspondence and secret voting has been established directly. However, with regard to the protection of other types of information of limited access, the Basic Law calls for the national legislation to ensure that the restrictions imposed are proportionate to the constitutionally recognized goals of the special legal regime of information.

In general, the legal regimes of restricted access information operate by introducing exceptions into essentially two different legal presumptions. First of all, to the presumption of free access to public and other information (established in part 1, 2 of Article 34 of the Constitution), where exceptions are justified by the need to protect information of particular importance to state and public interests. Secondly, the presumption of confidentiality of confidential information (correspondence secrets, etc.), where the main part provides mechanisms for its protection in public relations and in relations between a person and the state. But also as an exclusive element of legal regulation, it is necessary to use such information in accordance with the procedure established by legislation by a state body in order to prevent offenses, protect national interests and public order.

Thus, the restriction of access and dissemination of information is not associated with a violation of the constitutional right to information, but with the need to fully exercise other constitutional rights.

General provisions on the legal regime of information of limited access in Belarusian legislation are contained in the Law on Information. The bearer of the legal regime of restricted access information is administrative activity concerning the protection of the rights and interests of individuals, the state, and also public interests in connection with the circulation of information relating to various spheres of legal relations.

According to the norms of the Basic Law (Constitution of the Republic of Belarus), Articles 17, $18,18-1$, the Law on Information ${ }^{2}$, as well as the provisions of international documents ratified by the Republic of Belarus, such rights and interests are:

\footnotetext{
${ }^{1}$ Constitution of the Republic of Belarus 1994: rev. and additional, adopted. on rep. referend. November 24, 1996 and Oct 17. 2004 // National legal Internet portal of the Republic of Belarus. URL: http://www.pravo.by/ main.aspx?guid=2101 (access date: 10.17.2016).

${ }^{2}$ On information, informatization and protection of information: Law of the Republic of Belarus of November 10, 2008 № 455-3: as amended. Act of January 42014 № 102-3 // Legislation of the CIS countries: database. URL: http://base.spinform.ru/show_doc.fwx?rgn=25309 (access date: 03.21.2015).
} 
- the right of an individual to preserve the secrets of private and family life, the secrets of postal correspondence, telephone conversations (as well as the secrets of other forms of private communication using modern means of communication);

- the right of an individual to protect his personal data;

- public interests in the field of environmental protection, morality;

- state interests in the sphere of ensuring defense capability, territorial integrity, national security and law and order, in the sphere of international relations, as well as the interests of performing the functions of the state in regulating key spheres of social relations;

- national security interests, public interests, legal rights and interests of individuals and legal entities, in connection with information on the activities of the state body, legal entity, which constitute official information of limited distribution;

- interests of state bodies, individuals and legal entities, non-resident organizations (nonlegal entities) in connection with information constituting commercial, professional, banking and other secrets protected by law;

- public interests in the administration of justice, and professional interests of authorized bodies (their employees) in connection with the performance of official duties with the implementation of administrative, criminal proceedings and legal proceedings;

- interests of legal entities in connection with the regulation of the activities of state bodies, legal entities, and non-state institutions for the collection, processing, accumulation, protection, and provision of information of limited access in cases stipulated by law.

Based on the provisions of the Constitution of the Republic of Belarus and the Law on Information, the mode of information of limited access is a special administrative-legal regime established by the legislation of the Republic of Belarus additionally with respect to each of the types of information specified in Article 17 of the Law on Information and other restrictions in the sphere of information circulation, introduced by other legislative acts in connection with the introduction of other administrative-legal regimes.

Describing the legislation in the field of information of limited access in general, it should be noted differences in the quality and completeness of the regulatory and legal framework for different types of information. The same (special) legislative acts are devoted only to state secrets and trade secrets, in which the legislator has thoroughly approached the settlement of issues related to the protection and use of such information.

The Law of the Republic of Belarus "On State Secrets" [11] discloses the legal and organizational basis for classifying information as state secrets, protecting them, performing their functions by state bodies and officials in connection with their storage, providing access to them, and using state secrets in the process performance of functional duties.

The Law of the Republic of Belarus "On Commercial Secrets" [14] regulates relations arising in connection with the establishment, modification and cancellation of the regime of a commercial secret, as well as in connection with the legal protection of a commercial secret. Based on the regulatory definition of a trade secret, technical, industrial, organizational, commercial, financial or other information, including production secrets (know-how) of commercial value for their owner due to unknown to third parties, falls within its scope. The legal protection of information in the mode of a commercial secret requires the fulfillment of special conditions (Article 5), and the establishment of a set of measures for this information necessary to ensure their confidentiality (Article 8).

This law introduced into the Civil Code of the Republic of Belarus the concept of "undisclosed information" as an object of civil rights as a type of official secret or trade secret. Describing the content of undisclosed information, the norms of the article of the Code of the same name 
(Article 140), in general, correspond to the similar provisions of the Law of the Republic of Belarus "On Commercial Secrets".

In addition to the above legislative acts, the regulation of legal relations regarding information in the mode of commercial secret concerns such regulatory legal acts. Article 24 of the Law of the Republic of Belarus "On Commodity Exchanges" [19] states that relations connected with a commercial secret of a commodity exchange are governed by legislation on commercial secrets.

Chapter 6 of the Resolution of the Ministry of Justice of the Republic of Belarus "On Approval of the Rules of Professional Ethics of Persons Carrying Out Legal Services" [25] states that a lawyer, when rendering professional services, is obliged to respect the confidentiality of information about the customer's activities, including related to commercial activities, access to which is restricted in accordance with the legislation of the Republic of Belarus.

The protection of personal data in the Republic of Belarus is carried out on the basis of the Basic Law, the Law of the Republic of Belarus "On the Population Register", which contains the normative definition of information that constitutes the personal data of individuals, establishes the principles for ensuring the protection of personal data contained in the register, and monitoring the use of data is determined by the order of their use and protection [16].

The legal basis for the overhead mode is laid down by the Law on Information, where Article 18-1 defines the concept of such information. The Law on Information contains references to other regulatory legal acts specifying the list of information relating to official information. One of these documents is the Resolution of the Council of Ministers of the Republic of Belarus "On Official Information of Limited Distribution" dated April 12, 2014 No. 783, which defines the List of information relating to official information of limited distribution. The final item 141 of this List contains a broad interpretation of the concept of "other information", which constitutes proprietary information of limited distribution, which, in our opinion, leaves a wide space for discussions about the delimitation of definitions of such terms as "proprietary information", "bank secrecy", "professional secret" or other legally protected secret. Since such information in any case meets the criteria of potential danger " $<\ldots>$ national security, public order, morality, rights, freedoms and legitimate interests of individuals, including their honor and dignity, personal and family life, as well as the rights and legitimate interests of legal entities persons, organizations that are not legal entities" [17].

Regarding the term "banking secrecy", certain standards are introduced by the provisions of Article 121 of the Banking Code of the Republic of Belarus, which contains the content of information that is a banking secret: " $<\ldots$.. about accounts and deposits financial organization), its owner, number and other account details, the amount of funds held in accounts and deposits (deposits), as well as information about specific transactions, transactions without opening an account, transactions on accounts and deposits (deposits), and that also on the property deposited at the bank" [1].

The notion of attorney's secrets given in Article 1 of the Law of the Republic of Belarus "On the Bar and Advocacy in the Republic of Belarus" defines it as " $<\ldots$.. information about the issues on which the client requested legal assistance, the essence of consultations, clarifications, references received by the client from a lawyer, information about the client's personal life, information received from the client, about the circumstances of the crime in a criminal case in which the lawyer protected the rights, freedoms and interests of the client, as well as information constituting commercial client secret" [20].

Article 15 of the Law of the Republic of Belarus "On the provision of psychological assistance" uses the term "professional secrecy" and defines it as "information obtained in the provision of psychological assistance, as well as the fact of seeking psychological assistance" [21].

Article 46 of the Law of the Republic of Belarus "On Health care" provides a normative definition of the concept of medical confidentiality as "information about the fact that a patient has applied for medical help and his state of health, information about the presence of a disease, 
diagnosis, possible methods of medical care, risks associated with medical interventions, as well as possible alternatives to the proposed medical intervention, other information, including personal data, obtained when providing the patient with medical care, and in case of death - and infortion of the results of post-mortem examination" [12].

The results of the study of the above definitions and other regulatory legal acts allow us to conclude that the term "professional secrecy" unites a wide range of information obtained in the course of professional activity, and constituting the secret of personal and family life, trade secrets, as well as the essence of the issue whom the person has addressed to the professional services provider, or information reflecting the details and results of the provision of such services.

The basis of the legal regimes of information contained in administrative offenses cases, materials and criminal cases of the criminal prosecution authorities and the court until the completion of the proceedings is laid down in the legislative acts regulating the work of law enforcement agencies, and the procedure for conducting special activities necessary for them to perform their functions . Such acts are the Laws of the Republic of Belarus "On Operational-Search Activity" [22], "On State Protection of Judges, Law Enforcement Officials and Supervisory (Supervisory) Authorities, Employees of the State Guard Body" [10], Resolution of the Council of Ministers of the Republic of Belarus "On Approval Provisions on the procedure for applying security measures to protected persons" [24], and other regulatory legal acts.

It should be noted the existence of legislative acts establishing rights and obligations, mainly in relation to state bodies and officials in connection with the use or protection of information of limited access of different types, as well as laws clarifying the conditions of legal regimes of information of limited access of different types in connection with the specifics of subject to regulation, or performance by public authorities and officials of public functions. Such legal acts include the Laws of the Republic of Belarus: "On the Basics of Administrative Procedures" [23], "On Technical Regulation and Standardization" [18], "On the Procedure and Conditions for Detention of Persons" [15], "On Economic Insolvency (Bankruptcy)" [26], "On the State Control Committee of the Republic of Belarus and its territorial bodies" [13] and others.

Sanctions applied to persons who have violated the requirements of the law in relation to protected information by restricted access information regimes are established in the norms of the Administrative Violations Code of the Republic of Belarus and the Criminal Code of the Republic of Belarus [4; 27].

Conclusions and further researches directions. Summarizing all the above, we can conclude that information of restricted access is confidential or secret information, the legal status of which is provided for by national legislation, and the information itself is protected by its owner or holder in the manner prescribed by law.

Confidential information is made up of information that is owned, owned, used, or possessed by subjects of private law, which determine the procedure for storing, establishing access to such information, and the stages of its life cycle. Secrets are information constituting a state or other secret as provided by law, the disclosure of which is detrimental to national security, law and order, public order and morality, the legal rights and interests of individuals and legal entities, organizations without the status of a legal entity.

The application of restricted access legal regime to secret information should be prescribed by law. Secrets include: state secrets, trade secrets, bank secrets, proprietary information of limited distribution, professional secrets, law secrets, and other types of secrets ${ }^{3}$.

\footnotetext{
${ }^{3}$ Liaskouski I. Legal basis of restricted information mode. Confidential information. Secrets. The Economic Support of Human Rights: V International Scientific and Practical Conference, Section 2. Protection of Human Rights, Proceedings, Issue № 5, Kharkiv, February 23, 2018. Scientific Research Institute of Rights of the Second Generation "Kharkiv Social and Economic Institute", 2018. 100 p.
}

ISSN 2521-6473 


\section{References:}

1. Banking Code of the Republic of Belarus: Law of the Republic. Belarus from October 252000 № 441-W: in red. dated July 13, 2016 № 397-3 // Legislation of the CIS countries: database. URL: https://base.spinform.ru/show_doc.fwx?rgn=1991 (access date: 11.20.2017).

2. Universal Declaration of Human Rights: adopted by General Assembly resolution 217 A (III) of December 10, 1948 / United Nations. URL:: http://www.un.org/ru/ documents/decl_conv/declarations/declhr.shtml (access date: 10.17.2016).

3. Directive 95/46 / EC of the European Parliament and of the Council of 24 October 1995 on the protection of the rights of individuals in relation to the processing of personal data and on the free movement of such data. Garant: information and legal support. URL: http://base.garant. ru/2569783/1/ (access date: November 10, 2017).

4. Code of the Republic of Belarus on Administrative Offenses: Law Resp. Belarus of April 21, 2003 № 194-W: as ed. dated January 9, 2017 № 16-3 // Legislation of the CIS countries: database. URL: https://base.spinform.ru/show_doc.fwx?rgn=14895 (access date: 11.20.2017).

5. The Convention on Access to Information, Public Participation in Decision-making and Access to Justice in Environmental Matters (Aarhus Convention) of June 06, 1998 / United Nations. URL: http://www.un.org/ru/documents/decl_conv/conventions/orhus.shtml (access date: 10.17.2016)

6. Convention for the Protection of Human Rights and Fundamental Freedoms of November 4, 1950: amended and effective from November 1, 1998 // Wikisource. URL: https://ru.wikisource.org/wiki/European_convention_to_protection_pra_man_man_and_main_ freedom (access date: 10.17.2016).

7. Convention on the protection of individuals in the automated processing of personal data of January 28, 1981. Consultant Plus. URL: http://keysystems.ru/files/doc/zi/dir-95-45-ec.doc (access date: November 10, 2017).

8. United Nations Convention against Transnational Organized Crime of November 15, 2000 / United Nations. URL: http://www.un.org/ru/documents/decl conv/conventions/orgcrime. shtml (access date: 10.17.2016).

9. International Convention for the Suppression of the Financing of Terrorism of December 9, 1999 / United Nations. URL: http://www.un.org/ru/documents/decl_conv/conventions/ terfin.shtml (access date: 10.17.2016)

10. On State Protection of Judges, Law Enforcement Officials and Supervisory (Supervisory) Authorities, Employees of the State Guard Body: Law Resp. Belarus from Dec 13 1999 № 340-3: in red. from 4 Jan 2014 № 130-3 // Legislation of the CIS countries: database. URL: https://base.spinform.ru/show_doc.fwx?rgn=1943\#B4K20QGVN9 (access date: 11.20.2017).

11. On State Secrets: Law Resp. Belarus of July 19, 2010 № 170-3: in red. from Oct 23 2014 № 196-3 // Legislation of the CIS countries: database. URL: http://base.spinform.ru/show_doc. fwx?rgn=31609 (access date: 03.21.2015).

12. On Health care: Law Resp. Belarus of June 18, 1993 № 2435-XII: ed. from October 21 2016 № 433-3 // Legislation of the CIS countries: database. URL: https://base.spinform.ru/show doc.fwx?rgn=2010 (access date: 11.20.2017).

13. On the State Control Committee of the Republic of Belarus and its territorial bodies: Law Resp. Belarus of July 01, 2010 № 142-3: in red. dated July 11, 2014 № 177-3 // Legislation of the CIS countries: database. URL: https://base.spinform.ru/show_doc.fwx?rgn=31469 (access date: 11.20.2017).

14. On Commercial Secrets: Law Resp. Belarus dated January 5, 2013 № 16-3 // Legislation of the CIS countries: database. URL: http://base.spinform.ru/show_doc.fwx?rgn=56984 (access date: 03.21 .2015$)$. 
15. On the Procedure and Conditions for Detention of Persons: the Law of Rep. Belarus of June 16, 2003 № 215-3: as ed. of July 19, 2016 № 406-3 // Legislation of the CIS countries: database. URL: https://base.spinform.ru/show_doc.fwx?rgn=3692 (access date: 11.20.2017).

16. On the Population Register: Law Resp. Belarus of July 21, 2008 № 418-3: as ed. from 04 Jan 2015 № 233-3 // Legislation of the CIS countries: database. URL: https://base.spinform.ru/ show_doc.fwx?rgn=23951 (access date: 11.20.2017).

17. On proprietary information of limited distribution: Decisions of the Council of Ministers of the Republic of Belarus of 12 August. 2014 № 783: as amended. from Oct 202015 № 873 // Legislation of the CIS countries: database. URL: https://base.spinform.ru/show_doc.fwx?rgn=69450 (access date: 11.20 .2017$)$.

18. On Technical Regulation and Standardization: Law Resp. Belarus from January 5 2004 № 262-W: in red. from 24 oct. 2016 № 436-3 // Legislation of the CIS countries: database. URL: https://base.spinform.ru/show_doc.fwx?rgn=5547 (access date: 11.20.2017).

19. On Commodity Exchanges: the Law of Rep. Belarus of January 5, 2009 № 10-3: as ed. dated July 8, 2015 № 284-3 // Legislation of the CIS countries: database. URL: http://base.spinform. ru/show_doc.fwx?rgn=26228 (access date: 11.20.2017).

20. On the Bar and Advocacy in the Republic of Belarus: the Law of Rep. Belarus from 30 dec. 2011 № 334-3: in red. of July 11, 2017 № 42-3 // Legislation of the CIS countries: database. URL: https://base.spinform.ru/show_doc.fwx?rgn=48853 (access date: 11.20.2017).

21. On the provision of psychological assistance: Resp. Law. Belarus of July 1, 2010 № 153-3 // Legislation of the CIS countries: database. URL: https://base.spinform.ru/show doc.fwx?rgn=31471 (access date: 11.20.2017).

22. On Operational-Search Activity: Law Resp. Belarus of July 15, 2015 № 307-3 // Legislation of the CIS countries: database. URL: https://base.spinform.ru/show_doc.fwx?rgn=77612 (access date: 11.20 .2017$)$.

23. On the Basics of Administrative Procedures: Law Resp. Belarus from October 28 2008 № 433-W: in red. from January 92017 № 17-3 // Legislation of the CIS countries: database. URL: https://base.spinform.ru/show_doc.fwx?rgn=93131 (access date: 11.20.2017).

24. OnApproval Provisions on the procedure for applying security measures to protected persons: Resolution of the Council of Ministers of the Rep. Belarus from January 212016 № 44 // Legislation of the CIS countries: database. URL: https://base.spinform.ru/show_doc.fwx?rgn=82509 (access date: 11.20.2017).

25. On Approval of the Rules of Professional Ethics of Persons Carrying Out Legal Services: Decree of the Ministry of Justice of the Rep. Belarus of June 8, 2007 № 37: as amended. dated January 22, 2016 № 11 // Legislation of the CIS countries: database. URL: https://base.spinform.ru/ show_doc.fwx?rgn=17546\#A000000002 (access date: 11.20.2017).

26. On Economic Insolvency (Bankruptcy): Law Resp. Belarus of July 13, 2012 № 415-3: as ed. from 24 oct. 2016 № 439-3 // Legislation of the CIS countries: database. URL: https://base.spinform.ru/show_doc.fwx?rgn=53170 (access date: 11.20.2017).

27. Criminal Code of the Republic of Belarus: Law Resp. Belarus of April 21, 2003 № 194-W: as ed. dated January 9, 2017 № 16-3 // Legislation of the CIS countries: database. URL: https://base.spinform.ru/show_doc.fwx?rgn=14895 (access date: 11.20.2017). 